\title{
Hydrological and meteorological investigations in a periglacial lake catchment near Kangerlussuaq, west Greenland - presentation of a new multi-parameter data set
}

\author{
E. Johansson ${ }^{1,2}$, S. Berglund ${ }^{4}$, T. Lindborg ${ }^{1,3}$, J. Petrone ${ }^{2}$, D. van As ${ }^{5}$, L.-G. Gustafsson ${ }^{6}$, \\ J.-O. Näslund ${ }^{1,2}$, and H. Laudon ${ }^{3}$ \\ ${ }^{1}$ Department of Physical Geography, Bert Bolin Centre for Climate Research, Stockholm University, \\ 10691 Stockholm, Sweden \\ ${ }^{2}$ Swedish Nuclear Fuel and Waste Management Co, Box 250, 10124 Stockholm, Sweden \\ ${ }^{3}$ Department of forest ecology and management, Swedish University of Agricultural Science, \\ 90183 Umeå, Sweden \\ ${ }^{4}$ Hydroresearch AB, St. Marknadsvägen 15S (12th floor), 18334 Täby, Sweden \\ ${ }^{5}$ Geological Survey of Denmark and Greenland (GEUS), Øster Voldgade 10, 1350 Copenhagen, Denmark \\ ${ }^{6}$ DHI Sweden AB, Honnörsgatan 16, Box 3287, 35053 Växjö, Sweden \\ Correspondence to: E. Johansson (emma.johansson@skb.se)
}

Received: 15 October 2014 - Published in Earth Syst. Sci. Data Discuss.: 16 December 2014

Revised: 20 April 2015 - Accepted: 6 May 2015 - Published: 29 May 2015

\begin{abstract}
Few hydrological studies have been conducted in Greenland, other than on glacial hydrology associated with the ice sheet. Understanding permafrost hydrology and hydroclimatic change and variability, however, provides key information for understanding climate change effects and feedbacks in the Arctic landscape. This paper presents a new, extensive, and detailed hydrological and meteorological open access data set, with high temporal resolution from a $1.56 \mathrm{~km}^{2}$ permafrost catchment, with a lake underlain by a through-talik close to the ice sheet in the Kangerlussuaq region, western Greenland. The paper describes the hydrological site investigations and utilized equipment, as well as the data collection and processing. The investigations were performed between 2010 and 2013. The high spatial resolution, within the investigated area, of the data set makes it highly suitable for various detailed hydrological and ecological studies on catchment scale. The data set is available for all users via the PANGAEA database, http://doi.pangaea.de/10.1594/PANGAEA.836178.
\end{abstract}

\section{Introduction}

Future climate change is expected to be most pronounced in the Arctic region (Kattsov et al., 2005), and the terrestrial and aquatic ecosystems in the Arctic are predicted to undergo fundamental changes in the coming century (Vaughan et al., 2013). To enable predictions of the ecological response to changes in the hydrological and biogeochemical cycles, the understanding and prediction of these responses on the landscape scale have to be improved (Rowland et al., 2010). Hydrology is the key driver for transport of matter within and between ecosystems. To describe the potential future impact on periglacial areas, related to changes in the hydrological cycle in the Arctic, the understanding of present conditions needs to be improved. Woo (2012) summarizes the present knowledge of permafrost hydrology, and in Kane and Yang (2004), water balances from 39 Arctic catchments are presented. However, only few hydrological data sets from Arctic regions exist that contain necessary information on both surface and subsurface waters within the same catchment. This is due to the inaccessibility of these remote areas and the harsh climatic conditions there, but it is also the ef- 
fect of the relatively short period of the year when unfrozen water is present and can be monitored.

In this work, we present hydrological data obtained from a detailed site investigation performed within the framework of the Greenland Analogue Surface Project (GRASP). The study area, here referred to as the "Two Boat Lake" (TBL) catchment, is located close to the Greenland ice sheet in the Kangerlussuaq region, western Greenland (Fig. 1). The investigations were initiated in 2010, and have resulted in a wealth of information on hydrology, meteorology, geometry (surface topography, lake bathymetry, and regolith and active layer depths), properties and spatial distributions of vegetation and soils, hydrochemistry, soil temperature, and geochemical processes and properties of the limnic and terrestrial ecosystems within the catchment. The aim of GRASP is twofold. The first part is focused on how ecosystems develop and react in a long-term climate change perspective during an entire glacial cycle (Lindborg et al., 2013). The other part is aimed at improving the understanding of water exchanges between surface water and groundwater in a periglacial environment (Bosson et al., 2012, 2013).

The objective of the present paper is to describe the hydrological and meteorological installations and measurements in the TBL catchment, and to make the data set available to the scientific community. The aim of the hydrological field studies presented here was to identify and quantify the main hydrological processes in a periglacial lake catchment, thereby providing input to conceptual and mathematical modeling. In coming studies of the TBL site, this hydrological and meteorological data set will be used as a basis for the modeling of hydrological, biogeochemical, and ecological processes in the catchment.

\section{Site description}

The Kangerlussuaq region, comprising a hilly tundra landscape with numerous lakes, is the most extensive ice-free part of Greenland. Continuous permafrost, interrupted by through-taliks under larger lakes, covers the area. A permafrost depth greater than $300 \mathrm{~m}$ has been observed from temperature measurements in deep bedrock boreholes, $\sim 5-$ $6 \mathrm{~km}$ from TBL (Harper et al., 2011). An active layer of 0.15$5 \mathrm{~m}$, depending on soil type and vegetation cover, overlies the permafrost in the area from the settlement of Kangerlussuaq up to the ice sheet margin (van Tatenhove and Olesen, 1994). The regional climate is dry with a mean annual precipitation of $149 \mathrm{~mm}$ in Kangerlussuaq (uncorrected data; see Sect. 4.1) and with a mean annual air temperature of -5.1 ${ }^{\circ} \mathrm{C}$ (measured 1977-2011; Cappelen, 2014). Discharge measurements in the Watson River, which is the main river in the area, were performed in Kangerlussuaq during the period 2007-2013 with an average annual cumulative runoff of $370 \mathrm{~mm} \mathrm{yr}^{-1}$ (Hasholt et al., 2013). This is almost entirely meltwater from the ice sheet, since $94 \%$ of the Wat- son River drainage area is glaciated. No rivers outside the meltwater system are present in the area. Mostly small intermittent streams (often formed by ice wedges) transport surface water to the many lakes in the area. Many outlet streams of precipitation-driven lakes dry out during the main part of the year due to low precipitation. The low precipitation is also manifested through the relatively large number of saline lakes in the area (Hasholt and Anderson, 2003). This means that two main types of hydrological regimes in lakes can be identified in the area: lakes not in contact with the meltwater system driven by precipitation, and lakes receiving water mainly from the melting of the ice sheet.

The TBL catchment, with an area of $1.56 \mathrm{~km}^{2}$ and lake coverage of $24 \%$, is a precipitation-driven lake, situated approximately $500 \mathrm{~m}$ from the Greenland ice sheet and $25 \mathrm{~km}$ northeast of Kangerlussuaq (Fig. 1). The stream in the outlet (Fig. 1) of the lake connects to the proglacial water system from the ice sheet, but no inflow of ice sheet meltwater occurs. The catchment boundaries and lake bathymetry are well described by a local $5 \times 5 \mathrm{~m}$ digital elevation model (DEM), based on lidar measurements in the terrestrial parts of the catchment and echo-sounding investigations in the lake. The DEM is available in another data set in PANGAEA, http://doi.pangaea.de/10.1594/PANGAEA.845258.

The lake is underlain by a through-talik, an observation based on temperature data from a $225 \mathrm{~m}$ long borehole drilled in a $60^{\circ}$ inclination under the TBL (Harper et al., 2011). The mean temperature at $140 \mathrm{~m}$ depth in the bedrock under the lake was $1.25^{\circ} \mathrm{C}$, and there were no indications of decreasing temperatures in the deepest part of the borehole, which would have indicated a closed talik (Harper et al., 2011). This interpreted through-talik provides a possibility of hydrological contact between the lake surface water and the deep unfrozen groundwater system below the permafrost. There are several lakes of similar or larger size in the area (Fig. 1), many of which likely also maintain through-taliks. Thus TBL is probably hydraulically connected with other lakes in the region via taliks and perhaps also with unfrozen parts of the subglacial areas. Till and glaciofluvial deposits dominate the regolith in the TBL catchment (Clarhäll, 2011) and have a general depth ranging from 7 to $12 \mathrm{~m}$ in the valleys to 0 on the hill sides, where bedrock outcrops dominate. Petrone (2013) made radar observations indicating an aeolian silt layer thickness up to $1.5 \mathrm{~m}$ in the TBL catchment, underlain by an $\sim 10 \mathrm{~m}$ thick till layer. The vegetation in the TBL catchment area is dominated by dwarf-shrub heath (Clarhäll, 2011). The TBL site is accessible via a road from the Kangerlussuaq international airport, which makes the site relatively easily reachable, compared to most other Arctic locations. The relatively small catchment, enabling a detailed spatial coverage of measurements of catchment processes, in combination with the fact that the hydrological system is not directly influenced by meltwater from the ice sheet, was the main reason for selecting the TBL catchment as a case study area for periglacial hydrology and ecology. 

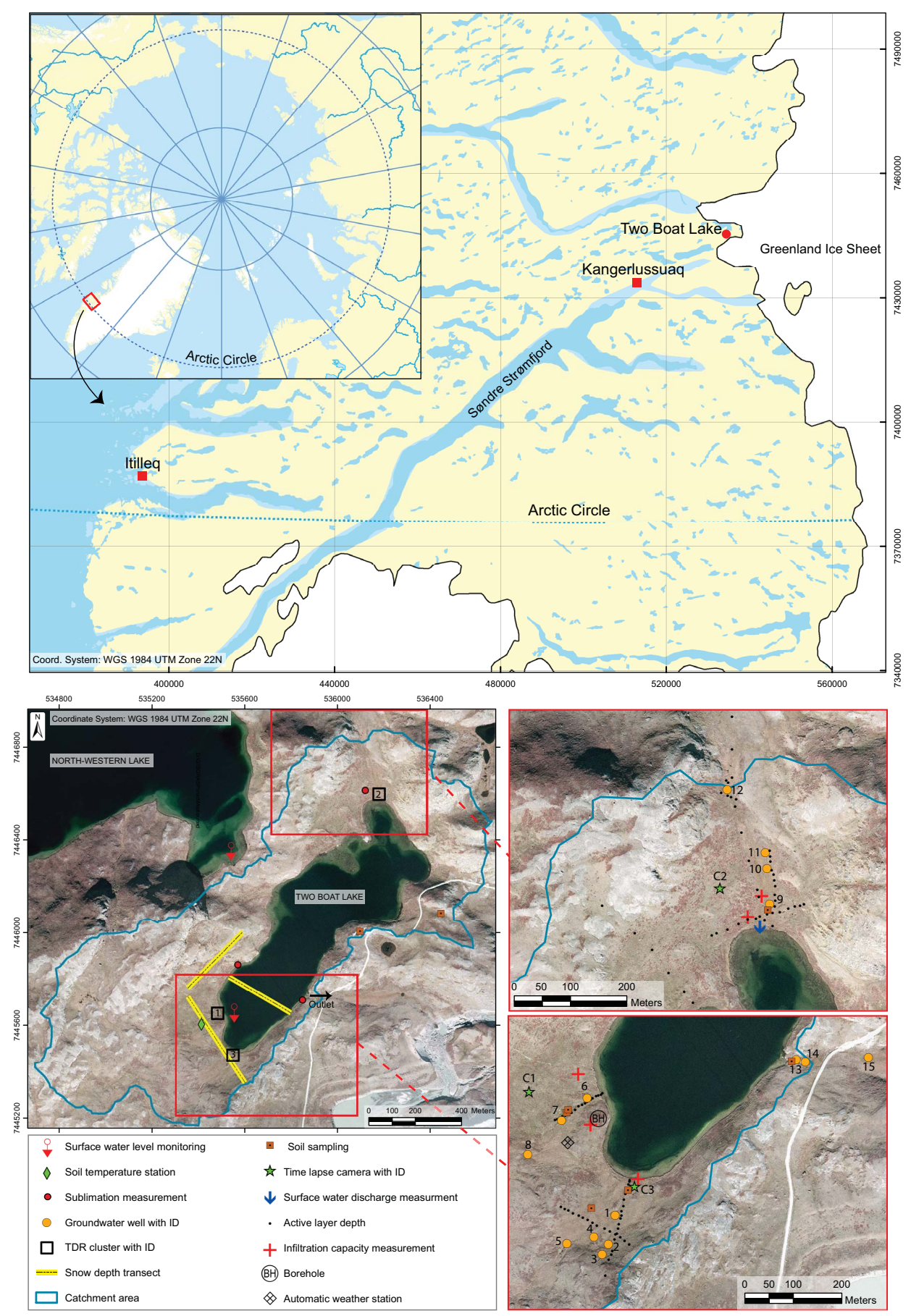

Figure 1. The regional area of Kangerlussuaq and the TBL catchment, installations, and sampling points.

\section{Installations and measurements}

\subsection{Strategy}

Besides the scientific questions to be answered, the measurement program was, to a large extent, determined by what was possible, given the hydrologic, climatic, and logistic conditions at the site. Due to its remote location, but also de- pending on the harsh climate, the site has only been manned during relatively short periods. This limited the possibilities for long-term or continuous observations of some parameters that could not be measured automatically (e.g., surface water inflow to the lake or groundwater monitoring in the active layer). Lack of infrastructure for electrical power and telecommunications has also been a limiting factor. 
Hydrological processes and conditions not considered in temperate climate regions may be of great importance in periglacial areas. Hydrological responses in these cold areas differ from catchments in boreal and temperate regions in fundamental aspects (Kane and Yan, 2004). Most importantly, the hydrology in periglacial environments is intimately connected to the presence of permafrost (White et al., 2007) and active layer dynamics. Snow-related processes (wind drift of snow and sublimation) have also been shown to be of great importance for the annual water balance (Reba et al., 2012; MacDonald et al., 2010).

The overarching target when planning the TBL field program was to identify and quantify the main hydrological processes including the interactions between surface water in the lake and in the surrounding catchment, and the role of both supra- and sub-permafrost groundwater. The dry climate and the very limited surface water runoff in the area imply that conventional discharge measurements are not meaningful; such measurements are otherwise a cornerstone in water balance studies (e.g., Johansson, 2008; Bosson et al., 2010). Hydrological processes and major events on different spatial scales have been captured by time-lapse cameras installed in the catchment. Figure 1 shows the hydrologically related installations and sampling points of the GRASP field program, and Table 1 summarizes all data presented in the present paper. An automatic weather station (AWS) constituted the platform for the hydrological investigations together with a monitoring program for soil water content, soil temperatures, groundwater levels in the active layer, and lake surface water levels. Data from all monitoring equipment, except from the AWS, were collected manually during field campaigns, either by manual measurements or by retrieving data from loggers. Typically three field campaigns per year (in April, June, and August-September) have been organized during the period for which data are presented.

\subsection{Meteorological data time series}

The AWS, labeled KAN_B, was installed at a $70 \mathrm{~m}$ distance from the lake on 13 April 2011 (Fig. 2). The station is similar to approximately 20 other AWSs installed on the ice sheet within the framework of the Programme for Monitoring of the Greenland Ice Sheet (PROMICE) (Van As et al., 2011), of which another 3 are located in the Kangerlussuaq region (Van As et al., 2012). The station at TBL measures air temperature $(\sim 2.55 \mathrm{~m}$ above ground $)$, air pressure, humidity ( $\sim 2.55 \mathrm{~m}$ above ground), wind speed and direction ( $\sim 3.05 \mathrm{~m}$ above ground), and the downward and upward components of shortwave (solar) and long-wave (terrestrial) radiation. A sonic ranger was mounted on the AWS to register changes in surface level due to the presence of snow. All variables were recorded every 10 minutes and processed to provide hourly averages. Values were stored locally, and hourly and daily averages were transmitted via satellite in

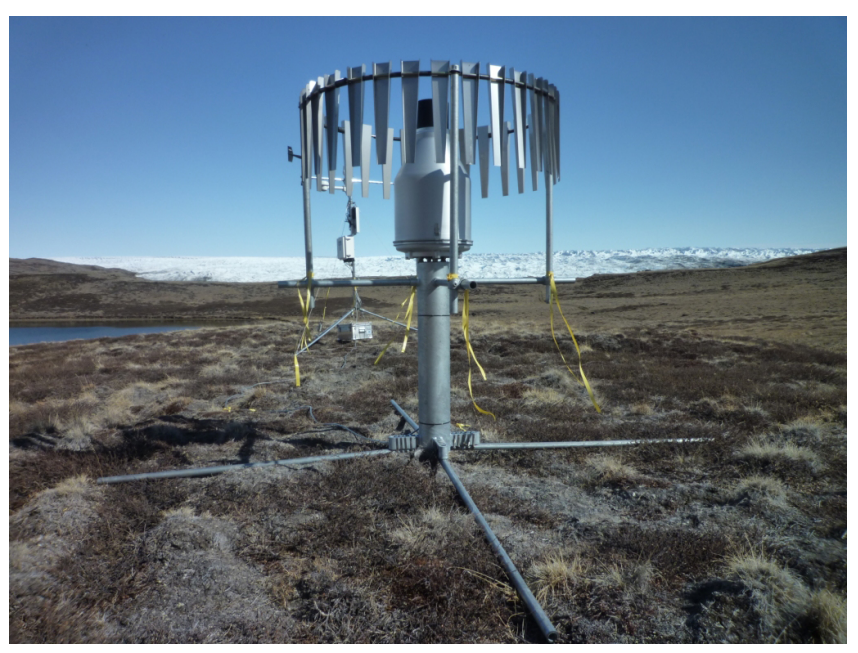

Figure 2. The automatic weather station (AWS) installed in April 2011.

summer and winter, respectively. Details about the instrumentation are given at http://www.promice.org.

An important addition to the station, compared to the PROMICE stations located on the ice sheet, is a precipitation gauge capturing both snow and rain. The snow is melted in the gauge and the snow water equivalent (SWE) is measured. A Geonor T-200B was used (http://www.geonor.com/ brochures/t-200b-series-all-weather.pdf), which weighs the precipitation in a $12 \mathrm{~L}$ bucket using a precision load cell with a vibrating wire transducer. The bucket initially contains a mixture of $2.4 \mathrm{~L}$ of ethylene glycol (antifreeze) and $3.6 \mathrm{~L}$ of methanol to melt captured solid precipitation, sealed from the atmosphere by $0.4 \mathrm{~L}$ of hydraulic oil to prevent evaporation.

Maintenence of the AWS occurred once a year and entailed reading out the high temporal resolution data from the logger, and replacing sensors for recalibration. On every visit, the liquid content of the precipitation gauge was removed before a replacement mixture of ethylene glycol and methanol was added.

\subsection{Sublimation and evaporation}

Observations in the TBL area show that the snow cover also decreased during some periods of freezing temperatures, especially during clear windy days in late winter. This indicates that sublimation could be a process of importance. Therefore, sublimation measurements were performed at three sites within the catchment (Fig. 1) during three clear and sunny days in April 2013. Even though measurements were performed during a short time period, they are judged to give a good estimation of the potential mass loss via snow sublimation. For each site, five white pans $(0.34 \mathrm{~m} \times 0.22 \mathrm{~m} \times$ $0.045 \mathrm{~m}$ ) were filled with snow and the weight of each box was noted. The mass loss was measured every $24 \mathrm{~h}$ with a precision scale in order to estimate the sublimation rate. 
Table 1. (a) List of equipment used, start of monitoring, time resolution, and accuracy for each parameter for all monitoring data.

\begin{tabular}{|c|c|c|c|c|}
\hline Parameter & Equipment & Monitoring started & Time resolution & Accuracy \\
\hline Soil temperature & HOBO U12-008 & Aug 2010 & $3 \mathrm{~h}$ & $\pm 0.25^{\circ} \mathrm{C}$ \\
\hline Soil moisture & TDR (CS615, CR1000) & Aug 2010 & $3 \mathrm{~h}$ & $\pm 2 \%$ \\
\hline $\begin{array}{l}\text { Hydrological events captured } \\
\text { by time-lapse cameras }\end{array}$ & $\begin{array}{l}\text { Canon Rebel T3 (1100D)/ Har- } \\
\text { bortronics DigiSnap } 2700\end{array}$ & Aug 2012 & $2 \mathrm{~h}$ & - \\
\hline Groundwater level & HOBO U20-001-04 & June 2013 & $0.5 \mathrm{~h}$ & $\pm 0.003 \mathrm{~m}$ \\
\hline Lake water level & Leveltroll 700 & Aug 2010 & $3 \mathrm{~h}$ & $\pm 0.1 \%$ \\
\hline Precipitation & Geonor T-200B & April 2011 & $10 \mathrm{~min}$ & \\
\hline $\begin{array}{l}\text { Air humidity, barometric } \\
\text { pressure, wind speed, } \\
\text { wind direction, long- and } \\
\text { shortwave radiation, air tem- } \\
\text { perature }\end{array}$ & See http://www.promice.org & April 2011 & See http://www.promice.org & See http://www.promice.org \\
\hline \multicolumn{5}{|c|}{ (b) List of measured parameters and investigation period for non monitoring data } \\
\hline Parameter & Sampling period & Number of samples & & \\
\hline Evaporation & Aug 2012 & Measured at $3 \times 5$ sites & & \\
\hline Sublimation & April 2013 & Measured at $3 \times 5$ sites & & \\
\hline Inflow to lake & June and Aug-Sept 2013 & Manually measured & & \\
\hline Snow depth & April 2011 & Manually measured & & \\
\hline Soil hydraulic conductivity & Aug 2013 & 26 cylinders & & \\
\hline Soil porosity & Aug 2010, Aug 2012, Aug 2013 & 76 cylinders & & \\
\hline Retention curve & Aug 2012, Aug 2013 & 37 cylinders & & \\
\hline Grain size distribution & Aug 2010, Aug 2012 & 20 samples & & \\
\hline Infiltration capacity & Aug 2012 & Measured at $5 \times 5$ sites & & \\
\hline
\end{tabular}

The same basic methodology was used when measuring evaporation in August 2013, i.e., the same pans were placed at the same sites during 3 days in August and the mass loss was measured. In this case, the boxes were filled with water and the mass loss due to evaporation was measured every day. No rain or snow was observed during the measuring period, which was characterized by variable clear and cloudy skies.

\subsection{Snow depth and snow water content}

The snow depth and associated snow water content were manually measured in April 2011. The catchment was subdivided into four domains: (i) areas without snow cover, (ii) intermediate areas with snow cover broken up by spots without snow in uphill areas and on steep slopes, (iii) valleys with snow cover, and (iv) the lake ice. Based on this classification, snow samples were taken along one transect in each domain, except domain type (i) (the transects are shown in Fig. 1). The snow depth was measured every $5 \mathrm{~m}$ along all transects. At every fifth depth location, snow samples were collected using a standardized snowtube sampler with an inner diameter of $4.5 \mathrm{~cm}$. The snow samples were weighed in the field using portable scales. The corresponding snow water contents were calculated using the known sample volumes.

\subsection{Water levels and discharge}

Surface water levels were monitored using pressure transducers placed at the lake bottom, both in TBL and in the lake located northwest of TBL (Fig. 1). The northwestern lake, which is located at an elevation of approximately $19 \mathrm{~m}$ above the TBL water level, is monitored with the purpose of getting a reference lake level fluctuation in the area. This is also a precipitation-driven lake but belongs to a different surface water system and discharges into a lake situated south of TBL. Details of equipment and measuring period are given in Table 1a. The transducers were placed at a minimum depth of $5 \mathrm{~m}$ to avoid disturbance from ice during the winter. A steel wire connected each transducer to the shore where it was firmly attached. Total pressure (hydrostatic and barometric) and temperature were logged every third hour.

The shallow active layer depth, in combination with the dry climate, results in unsaturated conditions in most of the active layer. This makes monitoring of groundwater levels complicated. Fifteen groundwater wells (of type PEH50, with inner diameter $41 \mathrm{~mm}$ ) were installed in the catchment to enable groundwater level monitoring and water sampling. The groundwater wells were primarily installed in local discharge areas along the valley's floor (Fig. 1) in order to maximize the possibility of getting the required volumes of water needed for chemical analyses.

The wells, consisting of a bottom plug and a fully screened pipe section, were installed with the bottom plug reaching the permafrost surface; the bottom plugs typically were at a depth of a few decimeters below ground surface. The ground surface and the top of casing (TOC) levels of each well were determined relative to the lake level (Table 2). Since no exact elevation reference point is present in the area, the reference level for all groundwater wells is the lake level at the start of 
Table 2. Levels of top of casing (TOC) and ground surface (relative the lake level, 4 September 2010) for each groundwater well relative to the lake surface. Automatic monitoring in the well is marked by an $\mathrm{X}$.

\begin{tabular}{rrrr}
\hline $\begin{array}{r}\text { Well } \\
\text { ID }\end{array}$ & $\begin{array}{r}\text { TOC } \\
\text { (m relative lake) }\end{array}$ & $\begin{array}{r}\text { Ground surface } \\
\text { (m relative lake) }\end{array}$ & $\begin{array}{r}\text { Automatic } \\
\text { monitoring }\end{array}$ \\
\hline 1 & 5.45 & 4.96 & $\mathrm{X}$ \\
2 & 8.85 & 8.23 & \\
3 & 12.35 & 11.6 & $\mathrm{X}$ \\
4 & 9.07 & 8.39 & $\mathrm{X}$ \\
5 & 12.19 & 11.8 & \\
6 & 4.79 & 4.16 & $\mathrm{X}$ \\
7 & 10.7 & 10.07 & \\
8 & 20.69 & 20.09 & $\mathrm{X}$ \\
9 & 4.73 & 3.98 & $\mathrm{X}$ \\
11 & 13.56 & 12.91 & \\
12 & 21.99 & 21.51 & $\mathrm{X}$ \\
13 & 0.2 & -0.38 & $\mathrm{X}$ \\
14 & -4.79 & -5.15 & $\mathrm{X}$ \\
15 & -22.31 & -22.77 & $\mathrm{X}$ \\
\hline
\end{tabular}

monitoring in September 2010. The groundwater levels in the wells were manually measured during field visits, and in the summer of 2013 the groundwater levels were automatically monitored by pressure transducers in 10 of the 15 wells (Table 2). The pressure transducers cannot handle frozen water, so the equipment was removed in the autumn.

Due to the very restricted amount of running water, no permanent discharge stations measuring surface water inflows to, or outflows from the lake were installed. Instead, a simple temporary installation was used to measure intermittent flowing surface water into TBL, led through a PVC pipe at the outlet of one of the main subcatchments of the area, where running water has been visible during wet periods. This small brook, shaped by ice wedges, dewatered the main part of the northern valley (Fig. 1). Manual measurements of this surface water inflow to the lake were made when field crew were present at the site in June and AugustSeptember 2013. Even though the total inflow to the lake was not captured in these measurements, they provided data supporting the development of the conceptual understanding of the site hydrology. In particular, the response to rain events and the magnitude of base flow and peak flow components could be analyzed. No surface water outflow has occurred in the lake since the project started, i.e., during the period 2010 2013, which means that the collection of such measurements was not possible.

\subsection{Soil water content}

Spatial and temporal variations of soil water content were monitored by use of the time domain reflectometry technique (TDR; Stein and Kane, 1983); details about the equipment are given in Table 1. In September 2011, 43 TDR-sensors were installed in three clusters, here referred to as clusters 13, within the catchment (Figs. 1, 3). Each cluster consists of a number of depth profiles where TDR sensors were placed, so that they cover the whole interval from just below the ground surface to the permafrost surface that constituted the bottom of the active layer at the time of installation. Clusters 1 and 2 consist of four depth profiles, where the four sensors in each profile were distributed evenly from a depth of $5-10 \mathrm{~cm}$ below ground to a depth of $40-50 \mathrm{~cm}$ (Fig. 3d). The sensors in cluster 3 were arranged in three depth profiles, each profile containing four sensors, which were placed along a transect from the lake into the catchment (Fig. 3c). The different clusters were arranged so that they form transects both along and transverse to the dominating flow direction (Fig. 3a), which generally was judged to be perpendicular to the lake shoreline.

The depth profiles of TDR sensors were installed in pits (one pit per profile) that were dug down to the distinct permafrost surface. Four TDR sensors were installed, with more or less constant distance between the sensors, so that it covered the entire depth in each particular pit. All TDR sensors in a cluster were connected to a central unit, consisting of a data logger, central electrical power, and an earth spike. A table describing the depth and ID code of each TDR sensor is available via http://doi.pangaea.de/10.1594/ PANGAEA. 836178

\subsection{Hydraulic properties of the soil in the active layer}

\subsubsection{Sampling}

Undisturbed soil samples were collected at four different depths in metal cylinders for analyses of soil water retention, total porosity, and saturated hydraulic conductivity (Fig. 4a, b). Since the hydraulic conductivity can be anisotropic, soil samples for saturated hydraulic conductivity measurements were collected both in the horizontal and the vertical direction. In addition, disturbed loose soil samples were collected for grain size analysis. Soil sampling was performed at four different sites (Table 3, Fig. 1). Samples taken in till areas and at the lake shore were subject to grain size analysis and total porosity measurements only.

The infiltration capacity of the soil was measured in $\mathrm{Au}-$ gust 2012 at five sites with different soil and vegetation cover (Table 3, Fig. 1) by using the double-ring infiltrometer method (Bouwer, 1986). Two cylinders were driven into the soil and water was added to both the inner and outer ring. The falling head method was applied, where the declining water level in the inner ring was measured as a function of time (Fig. 4c). The falling head was observed until steadystate conditions were reached, i.e., until the soil profile below the rings became saturated. At this moment the infiltration capacity (expressed as area-specific flow rate) provides the saturated hydraulic conductivity of the upper soil layer. 

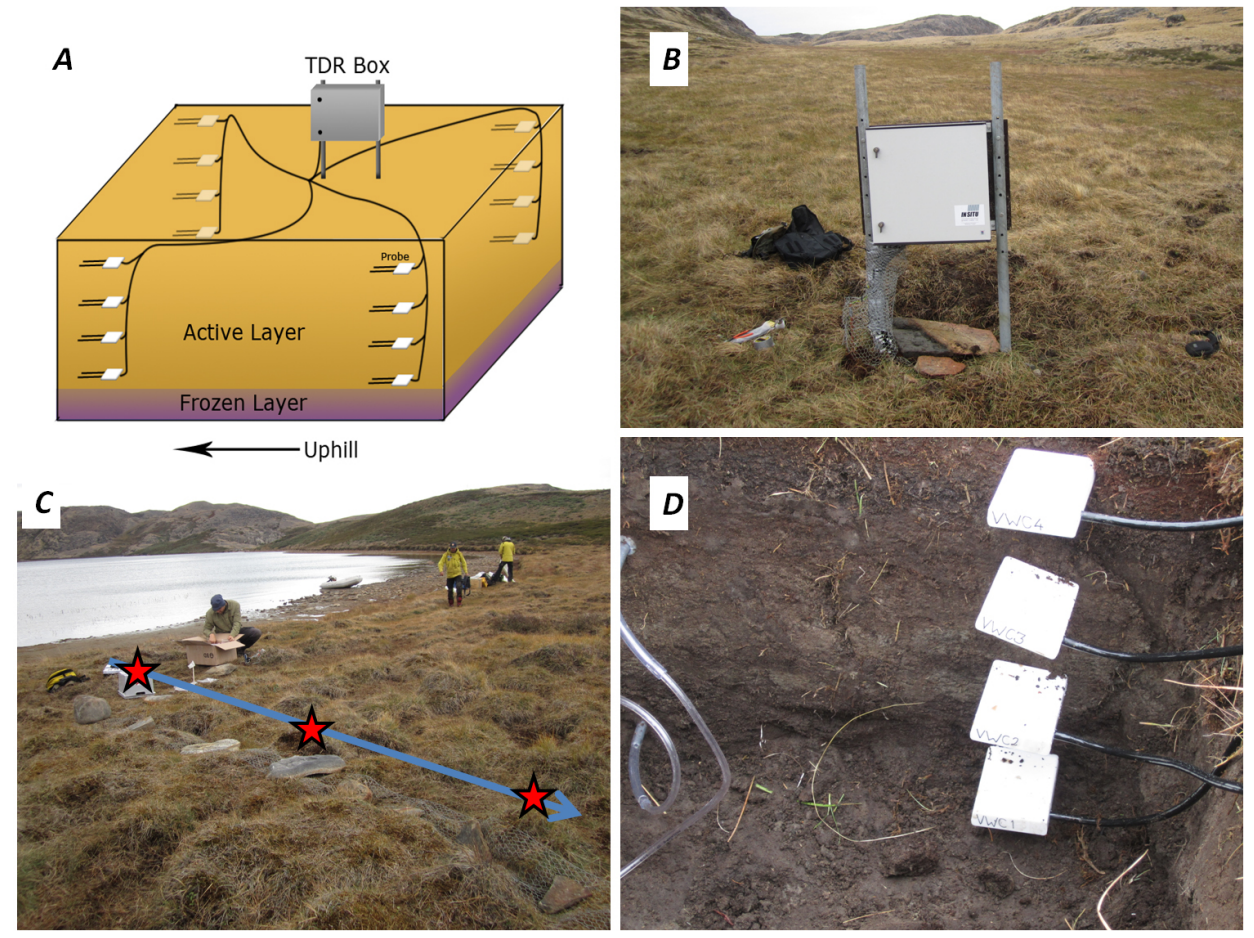

Figure 3. Schematic figure (a) and photo (b) of TDR installation no.1. Panel (c) shows a photo of the TDR transect no. 3, and a pit with four TDR sensors along a profile is shown in (d).

\subsubsection{Analyses of soil samples}

\section{Grain size distribution}

The grain size distributions of 20 samples were obtained in two steps. First the samples were sieved and divided into three groups: $d<2 \mathrm{~mm}, d=2-20 \mathrm{~mm}$, and $d>20 \mathrm{~mm}$. In the second step, the first group with grains less then $2 \mathrm{~mm}$ in diameter were divided into seven different fractions (Table 4). Both wet sieving and sedimentation by the pipette method were applied in the second step. In order to calculate the saturated hydraulic conductivity, both the Hazen and Gustafson methods were used (Andersson et al., 1984).

\section{pF curves}

Water retention parameters were measured in the laboratory (at the Swedish University of Agricultural Sciences in Uppsala). Water was added to the cylinders with undisturbed soil samples, described above, until saturated conditions were reached. The suction was increased in the steps from 0.05 , $0.3,0.5,0.7,1,2,3$, and $6 \mathrm{~m}$. At each suction step, the samples were left to drain until a steady state was reached.

\section{Saturated hydraulic conductivity}

Undisturbed soil samples collected in the metal cylinders, described above, were placed in a device equipped with water pipes that slowly added water to the cylinders. The samples were saturated and had free drainage at the bottom of the cylinders. Water was added at a constant rate and the outflow at steady-state conditions provided estimates of the saturated hydraulic conductivity.

\subsection{Soil temperature}

A soil temperature station consisting of seven subsurface temperature sensors distributed over a depth of $2 \mathrm{~m}$, and one sensor measuring air temperature at $1.6 \mathrm{~m}$ above ground, was installed in September 2010 (Figs. 1, 4d, and Table 1a). A hole with a diameter of approximately $60 \mathrm{~mm}$ was drilled through the active layer into the permafrost. In order to make sure that the sensors were placed at the right depths, the cables and sensors were attached to a PVC pipe, which was placed in the borehole. The sensors were connected to data loggers (Table 1a) that were installed in boxes placed on the ground surface; the boxes and cables were covered by a mound of stones in order to protect them from animals, ice, and snow.

Supporting information on the spatial distribution of the active layer thickness (i.e., the depth to the permafrost surface) was obtained by soil probe measurements along transects within the catchment (Fig. 1). The measurements were performed in late August or September when the active layer had reached its maximum thickness. 

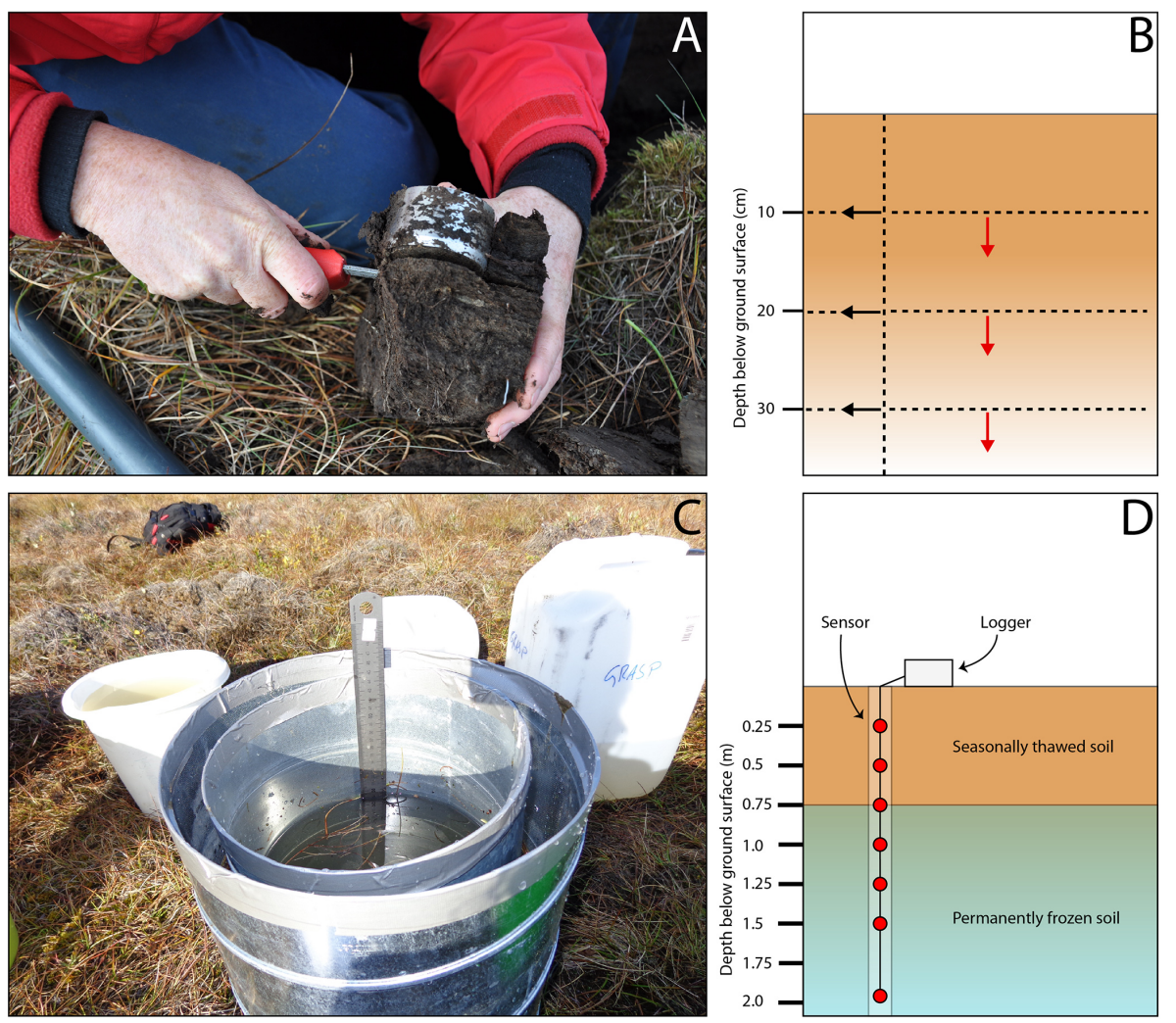

Figure 4. Photo of undisturbed soil samples (a), a schematic figure of methods for taking undisturbed soil samples for analysis of vertical (red arrow) and horizontal (black arrow) hydraulic conductivity (b), the infiltrometer used in the infiltration capacity measurements (c), and a schematic figure of the soil temperature station (d).

\subsection{Visual observations by time-lapse cameras}

Three time-lapse cameras were installed in August 2012 at different locations within the catchment (Fig. 1), with the purpose of monitoring hydrological events during the year and to support interpretations of the quantitative time series obtained from the AWS. The time-lapse camera installations provided very useful information for mapping local temporal variability in ponded water or snow cover, and to validate the snow models developed for the catchment. One camera was placed to give an overview of the whole catchment, $\mathrm{C} 1$ (Fig. 1), and the other two were placed to monitor details of hillslopes, C2 and C3 (Fig. 1), one in the southern part of the catchment (C2), and one in the northern part (C3). Photos were taken every second hour; the camera equipment is described in Table 1 a.

\section{Data processing}

\subsection{Correction of precipitation data}

The Geonor precipitation gauge collects the precipitation in a bucket and weighs the liquid with a vibrating load sensor that gives a frequency output. The output vibrating frequency to the logger contains noise that has to be accounted for, and the time series containing data on cumulative precipitation, given in millimeters, have been corrected accordingly. A thin layer of oil impedes evaporation losses, which means that any negative load can be neglected, and the first step of the correction was to delete all negative values from the time series.

Once the precipitation time series was corrected for noise, it had to be corrected for losses due to wind and adhesion. The gauge undercatch is in general larger for solid precipitation, and thus more important to take into account in Arctic environments than in areas where the main part of the precipitation falls as rain. The correction of precipitation is of special interest if the time series is used as input data in hydrological modeling, where an uncorrected precipitation may cause large water balance errors.

The location of the gauge was classified to be in number 6 out of 7 classes with respect to wind exposure; see Table 5 (Alexandersson, 2003), and the applied correction factors were in line with other work reported from Greenland (Hasholt, 1997; Førland et al., 1996). Losses due to adhesion were corrected for by adding $0.1 \mathrm{~mm}$ for every precipitation event in all classes 1-7. According to Alexandersson (2003), the Geonor precipitation gauges have been assigned an extra correction factor due to the larger height of the gauge result- 
Table 3. Soil sampling sites and types of analysis performed.

\begin{tabular}{|c|c|c|c|}
\hline \multicolumn{2}{|c|}{ Soil sampling sites } & \multicolumn{2}{|l|}{ Type of analysis } \\
\hline Sampling site* & Type of soil at surface & Undisturbed samples in metal cylinder** & Loose samples \\
\hline RS4 & Sandy silt & porosity & Grain size distribution \\
\hline RS5 & Till & porosity & Grain size distribution \\
\hline RS1 & Peaty silt & porosity, $K_{\mathrm{h}}, K_{\mathrm{V}}, \mathrm{pF}$ & Grain size distribution \\
\hline RS2 & Sandy silt & porosity, $K_{\mathrm{h}}, K_{\mathrm{V}}, \mathrm{pF}$ & Grain size distribution \\
\hline \multicolumn{4}{|c|}{ Sampling site for infiltration capacity } \\
\hline Peaty silt 1 & Peaty silt & & \\
\hline Peaty silt 2 & Peaty silt & & \\
\hline Sandy silt & Sandy silt & & \\
\hline Betula & Sandy silt & & \\
\hline Till area & Till & & \\
\hline
\end{tabular}

* RS is regolith sampling; the coordinates for each sampling site are given in the data set: http://doi.pangaea.de/10.1594/PANGAEA.836178. ** $K_{\mathrm{h}}$ is horizontal hydraulic conductivity, $K_{\mathrm{V}}$ is vertical hydraulic conductivity, and $\mathrm{pF}$ is retention curve.

Table 4. Intervals used in the grain size analysis.

\begin{tabular}{l}
\hline Grain size diameter, $\mathrm{mm}$ \\
$d<0.002$ \\
$0.002-0.006$ \\
$0.006-0.02$ \\
$0.02-0.06$ \\
$0.06-0.2$ \\
$0.2-0.6$ \\
$0.6-2$ \\
$2-20 \mathrm{~mm}$ \\
$>20 \mathrm{~mm}$ \\
\hline
\end{tabular}

ing in a higher wind exposure and higher potential risk for wind losses; see Table 5. The classes can be determined by studying photos and relevant spatial data from the site (tree and vegetation cover, topography). However, the best way to classify the gauge is to visit the station. In all correction calculations, a threshold temperature of $0^{\circ} \mathrm{C}$ was applied to determine if the precipitation had fallen as snow or rain.

The precipitation data from the station in Kangerlussuaq (Cappelen, 2014) were also corrected for wind and adhesion losses by applying the Alexandersson (2003) corrections from class 4 , Table 5 . The precipitation bucket used at the DMI station is not a Geonor, which means that the extra correction factor of $7 \%$ was excluded for the Kangerlussuaq data.

\subsection{Correction of pressure data}

The equipment used for the measurements of groundwater and surface water levels measured total pressure, which means that the pressure data had to be corrected for barometric pressure. Locally measured barometric pressure data were available from the AWS at TBL. In the correction of pressure data, barometric pressure was subtracted from the measurements of total pressure, resulting in time series of groundwater and surface water pressure fluctuations.

Only corrected pressure data are included in the data set presented in the present paper (see next section). The time series of lake level data (corrected for barometric pressure) was compared to manual measurements of the lake surface level, which was measured by a leveling instrument in August 2010, 2012, and 2013.

\section{Results}

In this section, the resulting hydrological and meteorological time series data and investigation results, achieved up until 31 December 2013, are presented. All parameters and time series presented in this paper are accessible in the database PANGEA via http://doi.pangaea.de/10.1594/ PANGAEA.836178. Date, time, and coordinates for each parameter are given in the metadata attached to the data files found via the DOI number, and each parameter presented is represented by an individual data file. A read-me file is linked to the data set, reached by the DOI link above, which all data users are strongly recommended to read. The name of every single data file, and the coupling between data files and the subsections describing results below, is listed in the read-me file. Hereafter the data reached via the DOI number above are referred to as "the data set".

\subsection{Climate data time series}

It is noted that a pronounced annual cycle in air temperature occurred at the study site (Fig. 5a). Non-freezing temperatures persisted throughout the summer months, with hourly values up to $15^{\circ} \mathrm{C}$ during the period covered by the data set. The highest measured daily average temperature recorded was $12.7^{\circ} \mathrm{C}$ and occurred during the extraordinary period 
Table 5. Classification of precipitation stations and correction factors based on exposure to wind.

\begin{tabular}{|c|c|c|c|c|}
\hline Class & Description & $\begin{array}{r}\text { Rain, } \\
\%\end{array}$ & $\begin{array}{r}\text { Snow, } \\
\%\end{array}$ & $\begin{array}{l}\text { Extra correction } \\
\text { for } \quad \text { Geonor } \\
\\
\text { gauges, } \%\end{array}$ \\
\hline 1 & $\begin{array}{l}\text { Ideal location, for example in a garden or wooded area with moderately high } \\
\text { shrubs or hedges near the gauge. }\end{array}$ & 1.5 & 4 & 3 \\
\hline 2 & Well protected in almost all directions, forest relatively close by. & 2.5 & 6 & 4.5 \\
\hline 3 & $\begin{array}{l}\text { Fairly well protected, but some smaller openings toward a larger field or lake } \\
\text { may occur. Well protected location if it is in a generally windy region. }\end{array}$ & 3.5 & 8.5 & 6 \\
\hline 4 & Fairly open location in some directions, better protected in other directions. & 4.5 & 12 & 7 \\
\hline 5 & $\begin{array}{l}\text { Open location with only some protection by buildings or trees. Placement on } \\
\text { hills or open slopes inland. }\end{array}$ & 6 & 17 & 7 \\
\hline 6 & Very open location, mostly coastal strips or mountain areas. & 9 & 26 & 7 \\
\hline 7 & $\begin{array}{l}\text { Extremely open location, on the outskirts of an archipelago, rocky island, or } \\
\text { bare mountain region above the tree line. }\end{array}$ & 12 & 36 & 7 \\
\hline
\end{tabular}
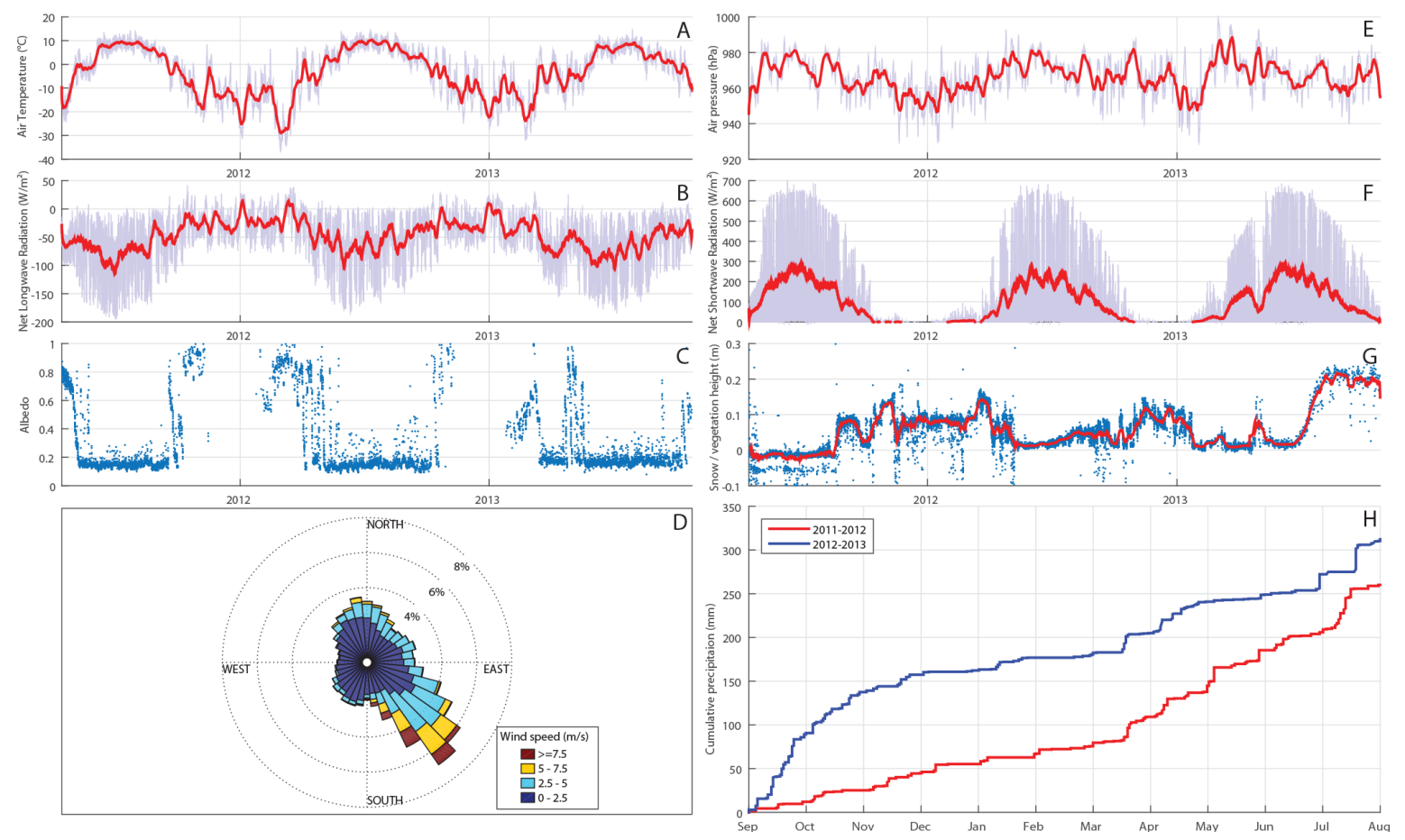

Figure 5. Climate data time series from April 2011 until December 2013. (a) Temperature $\left({ }^{\circ} \mathrm{C}\right)$, (b) net longwave radiation (W $\mathrm{m}^{-2}$ ), (c) albedo $(-)$, (d) wind speed $\left(\mathrm{m} \mathrm{s}^{-1}\right)$ and direction $\left({ }^{\circ} \mathrm{N}\right)$, (e) air pressure $(\mathrm{hPa})$, (f) net shortwave radiation $\left(\mathrm{W} \mathrm{m}{ }^{-2}\right),(\mathbf{g})$ snow depth/vegetation height $(\mathrm{m})$, and (h) cumulative precipitation $(\mathrm{mm})$.

in summer 2012 with ice sheet-wide melt (Nghiem et al., 2012) and record discharge in Watson River at Kangerlussuaq (Mikkelsen, 2014). Above freezing temperatures also occurred several times each winter, implying that there was more than one snow melt event per year. Winter temperatures were often in the range from -10 to $-20^{\circ} \mathrm{C}$, although hourly measurements could show temperatures below $-30^{\circ} \mathrm{C}$.

Wind speed was typically low, with values below $5 \mathrm{~m} \mathrm{~s}^{-1}$ (Fig. 5d). Events with wind speeds exceeding $10 \mathrm{~m} \mathrm{~s}^{-1}$ mostly occurred in winter. The highest recorded hourly wind speed was $18.6 \mathrm{~m} \mathrm{~s}^{-1}$, which indicates that the measurement site is somewhat sheltered compared to other locations in Greenland and on the ice sheet (Van As et al., 2014). Measured wind direction was likely impacted by the hilly terrain. In summer, the wind direction was almost exclusively from northeast to southeast, which means that it was mainly directed from the ice sheet. In other directions, the weather station is somewhat shielded by hills. In winter, when storms were more frequent, the situation was reversed and westerly winds were more common. Irrespective of the season, the 
strongest winds originated from the southeast (Fig. 5d), in which direction the distance to the ice sheet is only 1 kilometer.

For the measurement period (April 2011December 2013), barometric pressure was $966 \mathrm{hPa}$ on average. It was typically $\sim 20 \mathrm{hPa}$ lower in winter than in summer (Fig. 5e) due to the more frequent passage of low-pressure weather systems, also causing a larger wintertime variability in other meteorological parameters, such as temperature and wind speed. This was also the case for relative humidity, which was higher when snow was present on the ground surface and had an amplitude of 10-20\% in its annual cycle (not shown).

The air temperature cycle was also evident from the downward long-wave radiation measurements, which varied between a minimum of $\sim 150 \mathrm{~W} \mathrm{~m}^{-2}$ in winter and a maximum of $\sim 350 \mathrm{~W} \mathrm{~m}^{-2}$ in summer (not shown). Due to a larger upward emission of long-wave radiation from the surface, the net long-wave radiation balance was negative throughout most of the year, with energy losses exceeding $150 \mathrm{~W} \mathrm{~m}^{-2}$ in summer (Fig. 5b). This was more than compensated for by a positive net shortwave radiation balance, adding more than $600 \mathrm{~W} \mathrm{~m}^{-2}$ during sunny days in summer, heating the surface (Fig. 5f). During the short ( $\sim 1$ month) polar night, shortwave radiation was absent. Due to the presence of a highly reflective snow cover with broadband albedo values of $0.7-0.9$ (Fig. 5c), shortwave radiation contributed less than $100 \mathrm{~W} \mathrm{~m}^{-2}$ during $4-5$ months per year during the study period.

Surface height measurements illustrate that little snow accumulated at the weather station in winter, likely because it is situated on a small hill. In 2011/12 and 2012/13, roughly $10 \mathrm{~cm}$ accumulated (Fig. $5 \mathrm{~g}$ ). However, it should be noted that the snow cover was redistributed during storms and an irregular snow depth occurred at the site; for further details, see Sect. 5.3. In summer, a surface height increase of similar magnitude was recorded; this was due to vegetation growth as could be determined from the low albedo values of $\sim 0.16$ (Fig. 5c). Accordingly, data from the sonic ranger for the vegetation period (June-September) should not be interpreted as representing a snow cover, and the albedo can be used to distinguish snow from vegetation growth.

The annual corrected precipitation in 2012 was $365 \mathrm{~mm}$ and in 2013, it was $269 \mathrm{~mm}$; see Fig. 5h. The major part of the precipitation fell in April-May and August-October, and approximately $40 \%$ of the annual precipitation fell as snow. The measured precipitation at TBL was approximately twice as large as the precipitation measured in Kangerlussuaq. The precipitation in Kangerlussuaq is measured by DMI (Cappelen, 2014) and is not included in the data set presented at http://doi.pangaea.de/10.1594/PANGAEA.836178.

Time series with hourly data on corrected precipitation from April 2011 until December 2013 are included in the delivered data set. Hourly, daily, and monthly values are pre-
Table 6. Vertical $\left(K_{\mathrm{V}}\right)$ and horizontal $\left(K_{\mathrm{h}}\right)$ saturated hydraulic conductivity from undisturbed soil samples.

\begin{tabular}{lcc}
\hline Type of soil and depth, cm & $K_{\mathrm{h}}, \mathrm{m} \mathrm{s}^{-1}$ & $K_{\mathrm{V}}, \mathrm{m} \mathrm{s}^{-1}$ \\
\hline Peaty silt, 0-10 & $8.45 \times 10^{-5}$ & $4.83 \times 10^{-5}$ \\
Peaty silt, 10-20 & $5.76 \times 10^{-6}$ & $5.21 \times 10^{-6}$ \\
Sandy silt, 30-40 & $3.06 \times 10^{-6}$ & $2.66 \times 10^{-6}$ \\
\hline
\end{tabular}

sented in the data set for all other parameters measured by the AWS.

\subsection{Sublimation and evaporation}

The mean daily sublimation measured in April 2013 ranged from 0.39 to $1.06 \mathrm{~mm} \mathrm{day}^{-1}$, and the mean sublimation rate for all three sites during the whole measuring period was $0.63 \mathrm{~mm} \mathrm{day}^{-1}$. The average evaporation rate in the measurements performed in August 2013 ranged between 0.83 and $1.62 \mathrm{~mm} \mathrm{day}^{-1}$, with a mean evaporation for all three sites of $1.17 \mathrm{~mm} \mathrm{day}^{-1}$. The relatively simple sublimation and evaporation measurements performed provide valuable supporting information when calculating potential evapotranspiration, based on data from the AWS.

\subsection{Snow depth and snow water content}

Based on data from the investigated profiles, the average snow depth in the area in April 2011 was estimated to be $17 \mathrm{~cm}$, with a corresponding snow water equivalent (SWE) of $20 \mathrm{~mm}$. The largest snow depth was found in the valleys, and the smallest along the hillsides. At the time of measurement, the mean snow depth on the lake was similar to that of the whole catchment. However, time-lapse photos show that the snow cover on the lake was reduced to zero after certain periods of strong winds; for further details, see Sect. 5.8. Snow depth and corresponding SWE for each transect are presented in the data set.

\subsection{Hydraulic properties of the soil in the active layer}

\subsubsection{Saturated hydraulic conductivity and porosity}

The uppermost $10 \mathrm{~cm}$ of the active layer was characterized by high porosity and high saturated hydraulic conductivity $(K)$, which both decreased with increasing depth. There was no significant difference between the vertical and horizontal $K$ (i.e., insignificant anisotropy) in the peaty and sandy silt for which this difference was analyzed (Table 6 ). The $K$ values from undisturbed soil samples (in Table 6) were slightly lower than, but in the same order of magnitude as, the $K$ values calculated from grain size analysis of disturbed samples (Table 7). The till, which is a coarse till, had higher $K$ values than the silty material. In the lake outlet, both the $\mathrm{K}$ values and the porosity were high, even at greater depths. 
Table 7. Saturated hydraulic conductivity calculated from grain size analysis and total porosity from undisturbed soil samples.

\begin{tabular}{lrr}
\hline Type of soil and depth, cm & $K, \mathrm{~m} \mathrm{~s}^{-1}$ & Total porosity, \% \\
\hline Peaty silt, 0-10 & no data & 74.6 \\
Peaty silt, 10-20 & $9.01 \times 10^{-6}$ & 59.7 \\
Sandy silt, 30-40 & $8.27 \times 10^{-6}$ & 56.7 \\
Sandy silt 40-60 & $8.65 \times 10^{-6}$ & 54.6 \\
Lake outlet (sandy silt) & $4.86 \times 10^{-5}$ & 77.9 \\
Till, 15 & $2.81 \times 10^{-4}$ & 44.7 \\
Till, 45 & $8.26 \times 10^{-4}$ & 33.4 \\
\hline
\end{tabular}
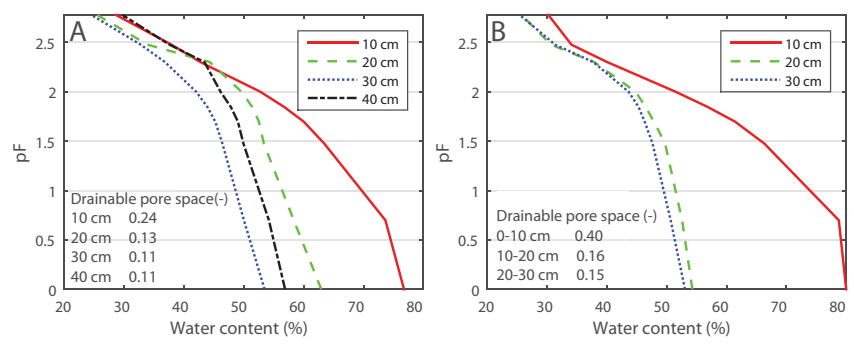

Figure 6. $\mathrm{pF}$ curves and drainable pore space (saturated water content - water content at field capacity) based on data from 40 undisturbed soil samples (a-b). Data from the 10 and $20 \mathrm{~cm}$ levels in (a) represent a peaty silt soil, and data from the 30 and $40 \mathrm{~cm}$ levels represent an aeolian silt. In (b), all data represent an aeolian silt.

\subsubsection{Infiltration capacity}

The average saturated infiltration capacity of all samples was $2.6 \times 10^{-4} \mathrm{~m} \mathrm{~s}^{-1}$. The range was small and no clear spatial pattern could be found. All measured values are presented in the data set.

\subsubsection{Water retention curves}

Water retention curves ( $\mathrm{pF}$ curves; see Fig. 6a-b) were obtained from undisturbed soil samples taken at different depths in two different types of soils: peaty silt and sandy silt. The high porosity in the upper $10 \mathrm{~cm}$ of the active layer was reflected as a high drainable pore volume (-) for both sample sites. The drainable pore volume decreased with depth and the values below $20 \mathrm{~cm}$ were in the same order of magnitude for both types of sampled soil. The drainable pore volume is defined as the difference between saturated water content and the water content at field capacity (denoted by $\mathrm{pF} 2$ ). Data from all sampling sites and associated results for hydraulic parameters ( $K$ values, porosity, infiltration capacity, and retention curves) are available in the data set.

\subsection{Water levels and discharge}

\subsubsection{Lake water level}

The annual variation in the lake water level in TBL was between 0.2 and $0.3 \mathrm{~m}$ (Fig. 7a). The dry spring and summer in 2011 caused a distinct decrease in lake level. The annual variation in the northwestern lake during the period 20122013 was $0.25 \mathrm{~m}$, and there was a clear covariation between the levels in the two lakes. The larger catchment and lake area make the northwestern lake somewhat less sensitive to short-term temporal variations. The corrected time series for both lakes are found in the data set.

\subsubsection{Groundwater level in the active layer}

All groundwater wells situated within the catchment showed similar temporal variations, whereas the temporal pattern in wells 13 and 14, situated downstream from the TBL catchment area, diverged from the wells inside the catchment. In Fig. $7 \mathrm{~b}$, the groundwater levels along the investigated transect in the northern part of the catchment are co-plotted with precipitation data. Two events with large increases in groundwater levels can be observed, namely the rain events around 26 July and 15 August 2013. At the beginning of the active period, decreasing groundwater levels were observed in well 12, located at the highest point along the monitored transect. Thawing of the active layer allowed water to percolate deeper into the saturated zone, at the same time as previously frozen groundwater was released and transported downstream. Wells 9 and 11 did not experience a falling groundwater level due to active layer thawing. These wells are located in local discharge areas in the lower parts of the hillslope, where thawed groundwater released at higher elevation discharged. The same pattern can be seen for the other transects. Time series for each of the wells $(1,3,4,6,8,9$, $11,12,13$, and 14) are found in the data set.

\subsubsection{Surface water discharge}

Inflow to the lake was measured during a week in June and from mid-August to the end of September 2013. There is a clear correlation between precipitation and surface water flow; see Fig. 7c. The small storage volume available for the groundwater, reflected in the rapid response in groundwater levels to precipitation, was further manifested by the quick response in surface water flows. When the second measurement period, illustrated in Fig. 7b, started in August, the discharge station was dry. Almost $90 \mathrm{~mm}$ of rain fell during the second measurement campaign, and the surface water discharge increased from 0 to approximately $0.2 \mathrm{~L} \mathrm{~s}^{-1}$. Peak flow occurred after a rain event of approximately $5 \mathrm{~mm}$, and the base flow increased during the whole measurement period in August-September. Time series data from both measurement periods (June and August-September) are included in the data set.

\subsection{Soil water content}

Time series data on soil water content, given as volume of water per total volume of soil, are available from late $\mathrm{Au}$ - 

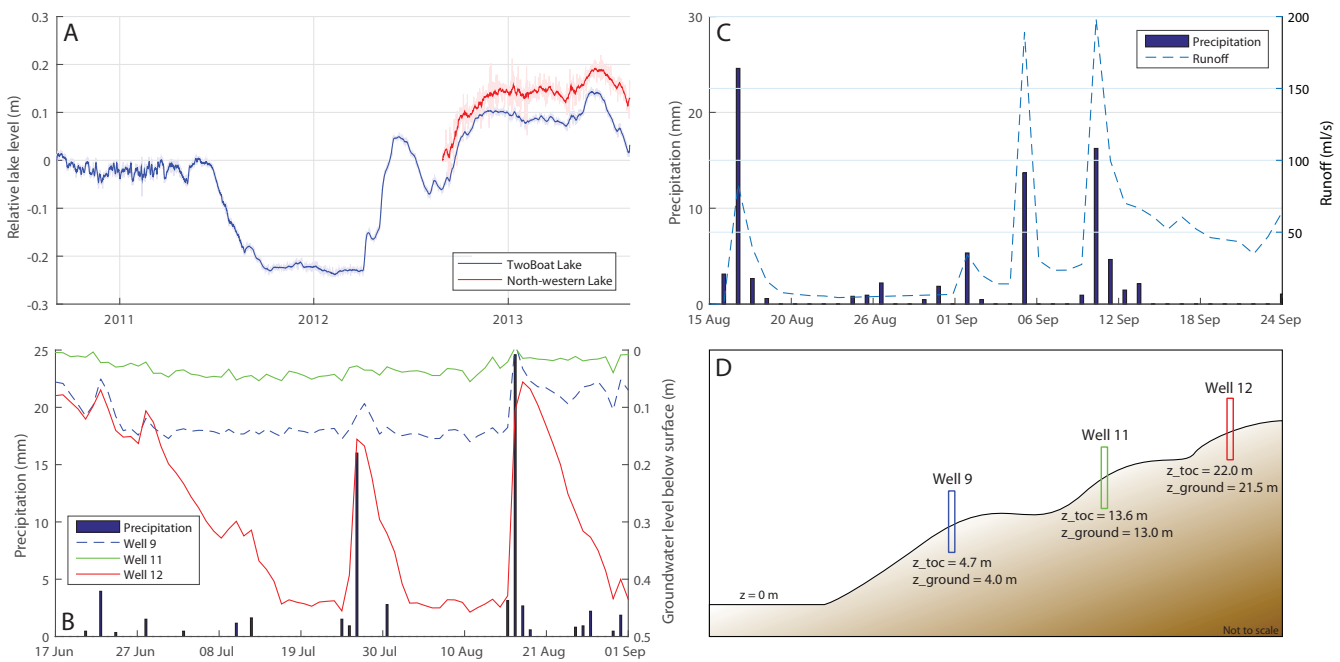

Figure 7. Lake level in TBL co-plotted with the lake level of the northwestern lake (a) and groundwater levels (b) along a transect (d), coplotted with precipitation data from the AWS. Measured surface water inflow, $\mathrm{mL} \mathrm{s}^{-1}$, to the northern part of TBL in August and September 2013, co-plotted with measured precipitation in the AWS, $\mathrm{mm} \mathrm{day}^{-1}$ (c).
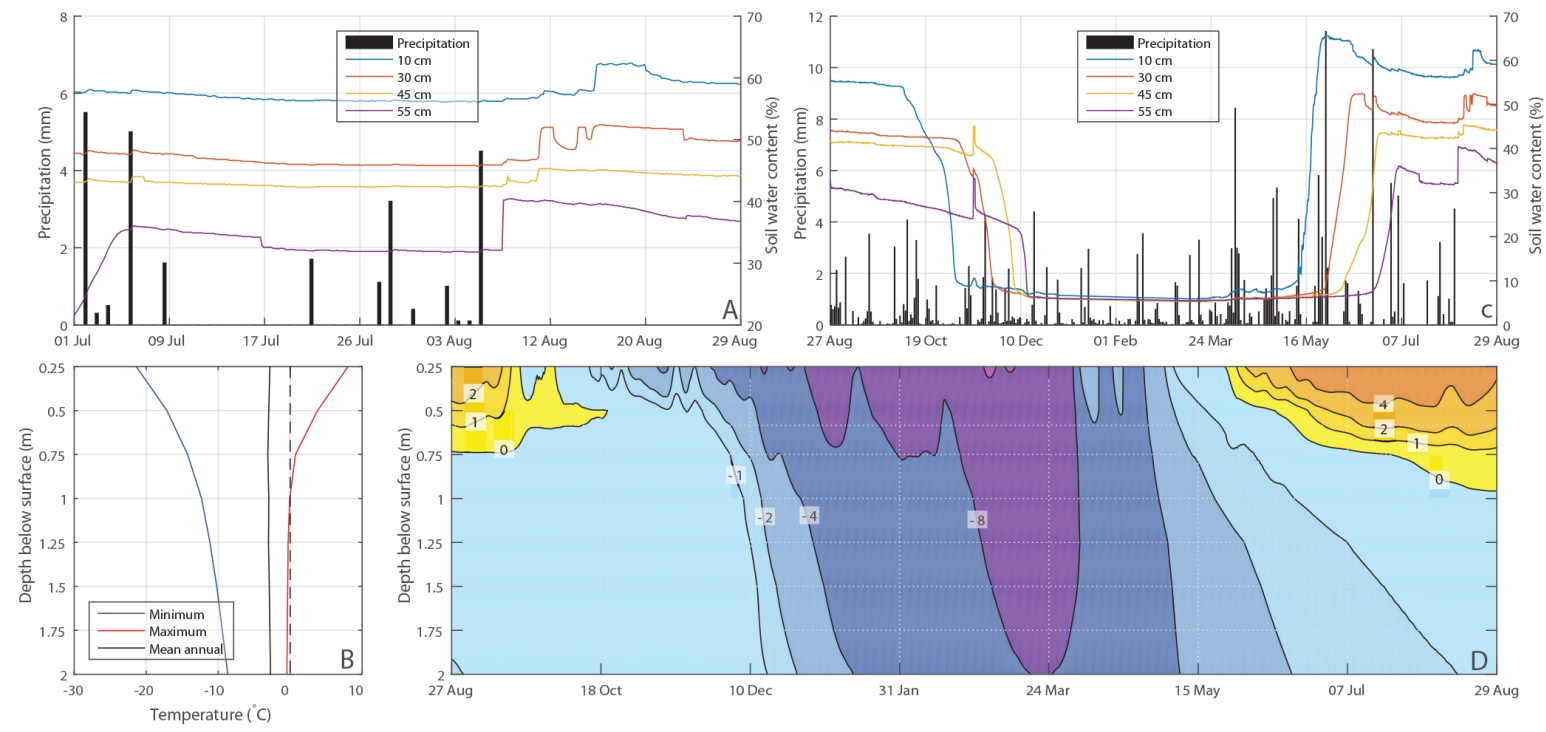

Figure 8. Soil water content (\%) at different depths co-plotted with precipitation (mm) data from the AWS, during the active period in 2012 (a) and the same data for the full year August 2011-August 2012 (c). Min, max, and mean soil temperature, ${ }^{\circ} \mathrm{C}$, as function of depth, based on data from August 2010 to August 2013 (b). Soil temperature in the upper $2 \mathrm{~m}$ from May 2012 to December 2012 (d).

gust 2011 until 31 December 2013. Data from all 43 sensors in the three TDR clusters (Fig. 1) are available in the data set. Figure 8a and c show examples of soil water contents at different depths as functions of time and precipitation during the period from August 2011 to August 2012, and in the summer of 2012. The depth trend in porosity (Sect. 5.4) is reflected as decreasing soil water contents with increasing depth; there is also an increasing delay in the response to rain events with increasing depth. The relatively low precipitation in July 2012 kept the soil water content in the upper $10 \mathrm{~cm}$ close to saturation, without affecting the deeper soil layers. The heavier rains in August quickly saturated the uppermost part $(10 \mathrm{~cm})$, and percolating water caused increased soil water content at the lower levels (i.e., at depths of 30,45 , and $55 \mathrm{~cm}$ ).

The quick changes in apparent soil water content during autumn and late spring were actually due to a phase change from water to ice or from ice to water in the soil matrix. Figure 8c-d illustrate how the active layer froze and thawed from the ground surface downwards, with the uppermost part of the active layer freezing and thawing approximately 2 months before the deepest parts. 


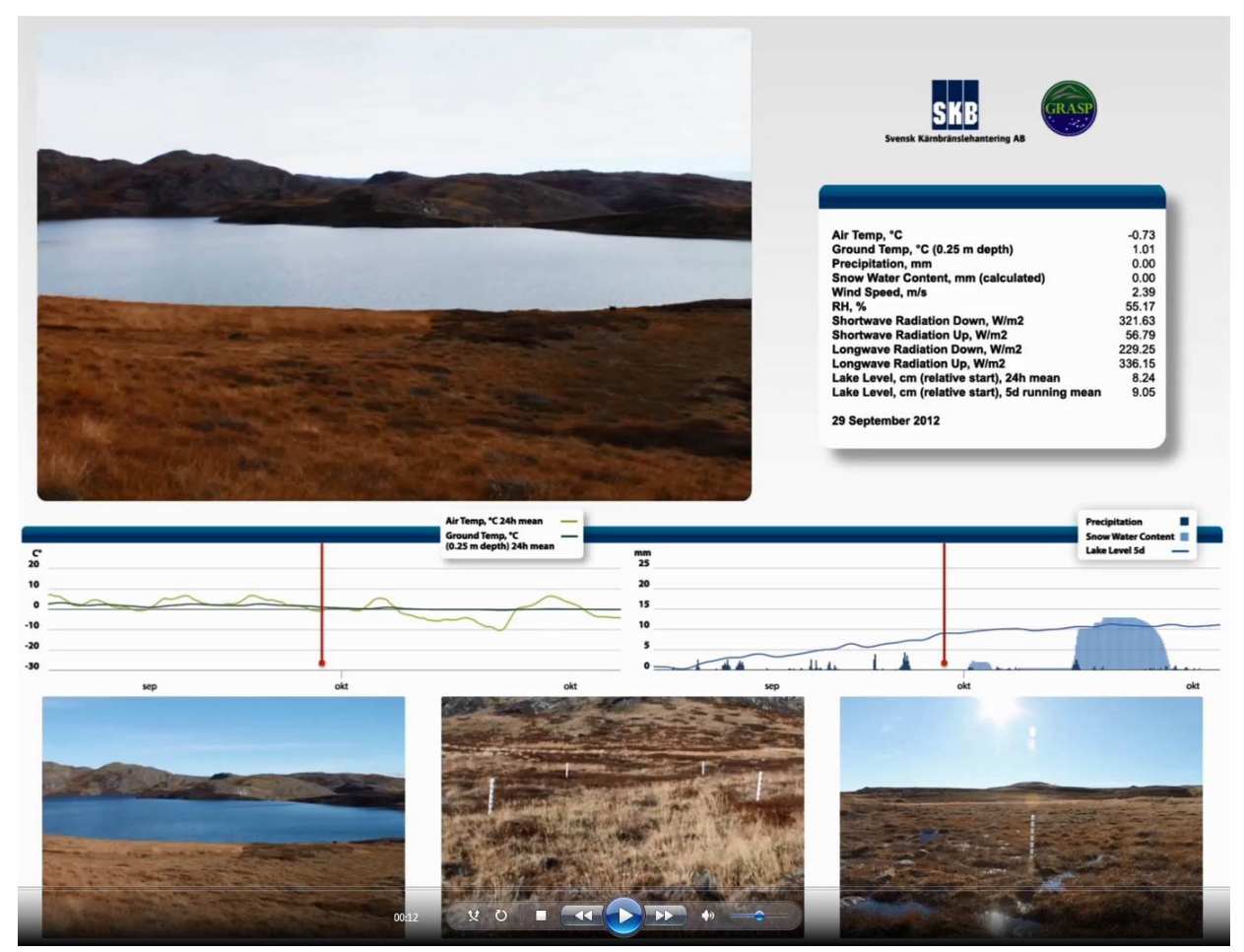

Figure 9. The user interface of the time-lapse film.

\subsection{Soil temperature}

At the location for the soil temperature measurements, the transition from permafrost to the active layer occurred at a depth of approximately $0.9 \mathrm{~m}$ (Fig. $8 \mathrm{a}, \mathrm{b}$ ). The temperature sensor at $0.75 \mathrm{~m}$ depth measured temperatures above $0{ }^{\circ} \mathrm{C}$ every year since the monitoring started, whereas the sensor at $1 \mathrm{~m}$ depth has continuously been frozen with a maximum temperature of $-0.1{ }^{\circ} \mathrm{C}$. The variations between the monitored years were relatively small. The thawing at a depth of $0.25 \mathrm{~m}$ in the active layer started in late May or early June and the freezing at that depth occurred in late September or early October. There is a decreasing covariation between air and soil temperatures with depth resulting in a delay of freezing and thawing at greater depth, i.e., the active layer both thawed and froze from above. The mean annual soil temperature at a depth of $0.5 \mathrm{~m}$ based on data from the period August 2010 to August 2013 was $-2.9^{\circ} \mathrm{C}$. Time series for each temperature sensor for the period August 2010 to December 2013 are available in the data set.

\subsection{Visual observations by time-lapse cameras}

Photos from all three cameras, together with time series data from the AWS, the soil temperature station, and the lake level monitoring, were put together in an interactive graphic interface (Fig. 9), hereafter called "the time-lapse film". The timelapse film facilitates the analysis of hydrological events and their spatial variations within the catchment. In Arctic land- scapes, observations by time-lapse cameras have been shown to be very useful in order to explain and analyze monitoring data, since conventional hydrological investigation techniques are not always applicable. The film has been used to analyze snow and lake ice dynamics, lake level response to precipitation and snow melt, and the occurrence of ponding water on the ground surface. The time-lapse film is available in the data set.

\section{Conclusions}

We present a new, extensive, and detailed data set with high temporal resolution for key hydrological parameters in an Arctic periglacial lake catchment. The high spatial resolution of the data, in this relatively small catchment area, makes the data set suitable for detailed hydrological and ecological catchment-scale studies. The data set also includes time series of photographs taken by time-lapse cameras, which have been arranged in an interface where photos, together with time series data from the catchment, can be studied in a film. This is a useful tool to test interpretations of the quantitative data. The data set is open access and available at http://doi.pangaea.de/10.1594/PANGAEA.836178.

Author contributions. Emma Johansson prepared the manuscript with contributions from all co-authors and she was involved in all field work and data processing related to the data presented in the present paper. 
Emma Johansson (hydrology and meteorology) and Tobias Lindborg (ecology and chemistry) are responsible for the GRASP field program.

Tobias Lindborg, Sten Berglund, Johannes Petrone, Lars-Göran Gustafsson, Jens-Ove Näslund, and Hjalmar Laudon were involved in the field work regarding the different measurement campaigns, as well as installations and maintenance of the equipment.

Dirk van As was responsible for installation and maintenance of the automatic weather station as well as post-processing of the climate data.

Acknowledgements. Thanks to John Cappelen, Danish Meteorological Institute, for providing climate data from the DMI station in Kangerlussuaq, and Christina Öhman, Swedish University of Agricultural Sciences, for help with the analysis of soil samples.

Edited by: A. Gelfan

\section{References}

Alexandersson, H.: Korrektion av nederbörd enligt enkel klimatologisk metodik, SMHI Report, Nr 111. 2003.

Andersson, A. C., Andersson, O., and Gustafson, G.: Brunnar - undersökning - dimensionering - borrning - drift, Rapport R42:1984, Byggforskningsrådet, 1984 (in Swedish).

Bosson, E., Sassner, M., Sabel, U., and Gustafsson, L. G.: Modelling of present and future hydrology and solute transport at Forsmark, SR- site biosphere, SKB R-10-02, Svensk Kärnbränslehantering $\mathrm{AB}$, Stockholm, 2010.

Bosson, E., Sabel, U., Gustafsson, L. G., Sassner, M., and Destouni, G.: Influences of shifts in climate, landscape, and permafrost on terrestrial hydrology, J. Geophys. Res., 117, D05120, doi:10.1029/2011JD016429, 2012.

Bosson, E., Selroos, J.-O., Stigsson, M., Gustafsson, L.-G., and Destouni, G.: Exchange and pathways of deep and shallow groundwater in different climate and permafrost conditions using the Forsmark site, Sweden, as an example catchment, Hydrogeology J., 21, 225-237, doi:10.1007/s10040-012-0906-7, 2013.

Bouwer, H.: Intake rate: Cylinder infiltrometer, in: Methods of soil analysis, Part 1. Physical and Mineralogical methods, edited by: Klute, A., Agronomic monograph no. 9, 2nd Edn., SSSA Book series: 5, Madison, Wisconsin, USA, 1986.

Cappelen, J. (Ed).: Weather and climate data from Greenland 19582013 - Observation data with description DMI Technical Report 14-08. 2014.

Clarhäll, A.: SKB studies of the periglacial environment - report from field studies in Kangerlussuaq, Greenland 2008 and 2010, SKB P-11-05, Svensk Kärnbränslehantering AB, 2011.

Førland, E. J., Allerup, P., Dahlström, B., Elomaa, E., Jonsson, J., Madsen, H., Perälä, J., Rissanan, P., Vedin, H., and Vejen, F.: Manual for operational correction of nordic precipitation data, DNMI Report nr. 24/96, Norwegian Meteorological Institute, 1996.
Harper, J., Hubbard, A., Ruskeeniemi, T., Claesson Liljedahl, L., Lehtinen, A., Booth, A., Brinkerhoff, D., Drake, H., Dow, C., Doyle, S., Engström, J., Fitzpatrik, A., Frape, S., Henkemans, E., Humphrey, N., Johnson, J., Jones, G., Joughin, I., Klint, K. E., Kukkonen, I., Kulessa, B., Londowski, C., Lindbäck, K., Makahnouk, M., Meierbachtol, T., Pere, T., Pedersen, K., Petterson, R., Pimentel, S., Quincey, D., Tullborg, E. L., and van As, D.: The Greenland Analogue Project Yearly Report 2010, Svensk Kärnbränslehantering AB, Report SKB R-11-23, 2011.

Hasholt, B.: Runoff patterns in Greenland, Northern Research Basins: Proc. 11th Int. Symp. and Workshop, Vol. 1, 71-81, Fairbanks, AK, 1997.

Hasholt, B. and Anderson, J.: On the formation and stability of oligosaline lakes in the arid, low arctic area of Kangerlussuaq, south-west Greenland. Proceedings of te northern research basins, 14th Internationl Symposium and Workshop, 2003.

Hasholt, B., Mikkelsen, A. B., Nielsen, M. H., and Larsen, M. A. D. Observations of Runoff and Sediment and Dissolved Loads from the Greenland Ice Sheet at Kangerlussuaq, West Greenland, 2007 to 2010, Z. Geomorph., 57, 3-27, 2013.

Johansson, P. O.: Description of surface hydrology and near surface hydrogeology at Forsmark, Site descriptive modelling, SDMSite Forsmark, SKB R-08-08, Svensk Kärnbränslehantering AB, 2008.

Kane, D. L. and Yang, D. (Eds.): Overview of water balance determinations for high latitude watersheds, in: Northern Research Basins Water Balance, International Association of Hydrological Sciences, IAHS Publication 290, Wallingford, UK, 271 pp., 2004.

Kattsov, V. M., Kallen, E., Cattle, H., Christensen, J., Drange, H., Hanssen, Bauer, I., Johannesen, T., Karol, I., Raisanen, J., Svensson, G., Vavulin, S., Chen, D., Polyakov, and Rinke, A.: Future climate change: Modeling and scenarios for the Arctic, in: Arctic Climate Impact Assessment Cambridge University Press, Cambridge, UK, 99-150, 2005.

Lindborg, T., Brydsten, L., Sohlenius, G., Strömgren, M., Andersson, E., and Löfgren, A.: Landscape development during a periglacial cycle: Modelling ecosystems from the past into the future, Ambio, 42, 402-413, doi:10.1007/s13280-013-0407-5, 2013.

MacDonald, M. K., Pomeroy, J. W., and Pietroniro, A.: On the importance of sublimation to an alpine snow mass balance in the Canadian Rocky Mountains, Hydrol. Earth Syst. Sci., 14, 14011415, doi:10.5194/hess-14-1401-2010, 2010.

Mikkelsen, A. B.: Freshwater discharge and sediment transport to Kangerlussuaq Fjord, West Greenland - processes, modelling and implications, $\mathrm{PhD}$ Thesis, Faculty of Science, University of Copenhagen, January 2014.

Nghiem, S. V., Hall, D. K., Mote, T. L., Tedesco, M., Albert, M. R., Keegan, K., Shuman, C. A., DiGirolamo, N. E., and Neumann, G.: The extreme melt across the Greenland ice sheet in 2012 Geophys. Res. Lett., 39, L20502, doi:10.1029/2012GL053611, 2012.

Petrone, J.: Using ground-penetrating Radar to Estimate Sediment Load in and Around TwoBoatLake, Western Greenland. (Student paper), Uppsala University, 2013.

Reba, M. L., Pomeroy, J., Marks, D., and Link, T. E.: Estimating surface sublimation losses from snowpacks in a mountain catch- 
ment using eddy covariance and turbulent transfer calculations, Hydrol. Process. 26, 3699-3711, doi:10.1002/hyp.8372, 2012.

Rowland, J. C., Jones, C. E., Altmann, G., Bryan, R., Crosby, B. T., Hinzman, L. D., Kane, D. L., Lawrence, D. M., Mancino, A., Marsh, P., McNamara, J. P., Romanvosky, V. E., Toniolo, H.. Travis, B. J., Trochim, E., Wilson, C. J., and Geernaert, G. L.: Arctic Landscapes in Transition: Responses to Thawing Permafrost, Eos, Transactions American Geophysical Union, doi:10.1029/2010EO260001, 2010.

Stein, J. and Kane, D. L.: Monitoring the Unfrozen Water Content of Soil and Snow Using Time Domain Reflectometry, Water Resour. Res., 19, 1573-1584, 1983.

Van As, D., Fausto, R. S., and PROMICE Project Team: Programme for Monitoring of the Greenland Ice Sheet (PROMICE): first temperature and ablation records, Geol. Surv. Denmark Greenland Bull., 23, 73-76, 2011.

Van As, D., Hubbard, A. L., Hasholt, B., Mikkelsen, A. B., van den Broeke, M. R., and Fausto, R. S.: Large surface meltwater discharge from the Kangerlussuaq sector of the Greenland ice sheet during the record-warm year 2010 explained by detailed energy balance observations, The Cryosphere, 6, 199-209, doi:10.5194/tc-6-199-2012, 2012.

Van As, D., Andersen, M. L., Petersen, D., Fettweis, X., Van Angelen, J. H., Lenaerts, J. T. M., Van Den Broeke, M. R., Lea, J. M., Bøggild, C. E., Ahlstrøm, A. P., and Steffen, K.: Increasing meltwater discharge from the Nuuk region of the Greenland ice sheet and implications for mass balance (1960-2012), J. Glaciol., 60, 314-322, doi:10.3189/2014JoG13J065, 2014.
Van Tatenhove, F. G. M. and Olesen, O. B.: Ground Temperature and Related Permafrost Characteristics in West Greenland, Permafrost Periglac. Proc., 5, 199-215, 1994.

Vaughan, D. G., Comiso, I., Allison, J., Carrasco, G., Kaser, R., Kwok, P., Mote, T., Murray, F., Paul, J., Ren, E., Rignot, O., Solomina, K., Steffen, and Zhang, T.: Observations: Cryosphere, in: Climate Change 2013: The physical Science Basis. Contribution of working group 1 to the Fifth Assessment Report of the Intergovernmental Panel on Climate Change, edited by: Stocker, T. F., Qin, D., Platter, G.-K., Tignor, M., Allen, S. K., Boschung, J., Nauels, A., Xia, Y., Bex, V., and Midgley, P. M., Cambridge University Press, Cambridge, United Kingdom and New York, NY, USA, 2013.

White, D., Hinzman, L., Alessa, L., Cassano, J., Chambers, M., Falkner, K., Francis, J., Gutowski Jr., W. J., Holland, M., Holmes, R. M., Huntington, H., Kane, D., Kliskey, A., Lee, C., McClelland, J., Peterson, B., Rupp, T. S., Straneo, F., Steele, M., Woodgate, R., Yang, D., Yoshikawa, K., and Zhang, T.: The arctic freshwater system: Changes and impacts, J. Geophys. Res., 112, G04S54, doi:10.1029/2006JG000353, 2007.

Woo, M.-K.: Permafrost Hydrology, Springer, 2012. 